\title{
CONSUMERS' COMPLAINTS: CAUSAL ATTRIBUTION AND MORAL EMOTIONS IN SERVICE FAILURES
}

Reclamações de Consumidores: Atribuição causal e emoções morais em falhas de serviço

\author{
Lude Marieta Gonçalves dos Santos Neves ${ }^{1}$ \\ ORCID: http://orcid.org/0000-0001-9815-7564 \\ E-mail: ludemarietag@gmail.com \\ Fabio Iglesias ${ }^{1}$ \\ ORCID: http://orcid.org/0000-0002-2217-5296 \\ E-mail: iglesias@unb.br \\ ${ }^{1}$ Universidade de Brasília, Brasília, Brasil
}

\begin{abstract}
Purpose: This research investigated consumers' reactions to service failures, based on Weiner's attribution theory, by simulating two situations: a teacher that is late to class and a delay in a course registration service.

Method: Students at an educational service $(n$ = 388) responded to four versions of scenarios, combining external and internal causes with teacher delay and enrollment problems.

Findings: Factor analyzes inductively reflected the theoretical organization of the model: Negative Behavior, Positive Reactions, Internal Attributions, and Negative Emotions. Internal causes led to internal attributions, negative emotions and negative behaviors.
\end{abstract}

\section{Resumo}

Objetivo: Esta pesquisa investigou as reações de consumidores a falhas de serviço, baseado na teoria atribucional de Weiner, simulando duas situações: atraso do professor e demora do atendimento para matrícula.

Método: Alunos de um serviço educacional ( $n$ = 388) responderam a quatro versões de cenários, combinando causas externas e internas com o atraso do professor e problemas na matrícula.

Resultados: Análises fatoriais refletiram de maneira indutiva a organização teórica do modelo: Comportamentos Negativos, Reações Positivas, Atribuições Internas e Emoções Negativas. Causas internas geraram 
Originality: The central role of moral emotions on the attitude towards complaining behavior is discussed, as well as the importance of implementing simple and lowcost managerial measures to improve the quality of care service.

Keywords: Service failures; Consumer behavior; Educational services. atribuições internas, emoções negativas e comportamentos negativos.

Originalidade: Discute-se $o$ forte papel exercido pelas emoções morais na atitude frente a reclamar e a importância de se propor medidas gerenciais simples e de baixo custo para aprimorar a qualidade de serviço de atendimento.

Palavras-chave: Falhas de serviço; Comportamento do consumidor; Serviços educacionais.

This work is licensed under a Creative Commons Attribution 4.0 International License: https://creativecommons.org/licenses/by/4.0/

\section{INTRODUCTION}

Complaints and conflicts between employees and customers are very common in a context in which product purchase or service hiring are the basis for a substantial portion of human interactions. However, the field of consumer behavior still does not offer robust answers when the aim is to understand students as consumers of educational services. For example, what kind of reactions do school students have when they identify failures at school? What influences these reactions and how does the event interpretation process occur until they decide to react? This research investigated factors that influence complaining behavior among vocational and technical education (VTE) students in Brazil, using Weiner's (2006) causal attribution theory.

Weiner's theory has been revised regarding its theoretical and applied approach (Graham, 2020). It is shown to be useful on trying to explain complaining behavior when a consumer identifies a service failure either in retail banks (Srivastava \& Gosain, 2020), in restaurants (Byun \& Jang, 2018), or in airports (Folkes et al., 1987), for instance. Some authors even emphasized the effect of moral emotions on complaining behavior (Qiu et al., 2018; Harrison-Walker, 2019), by arguing that it is difficult to adequately explore the phenomenon without investigating internal variables.

Studying complaints in diverse countries using Weiner's (2006) theoretical model requires a series of cultural adaptations in terms of vocabulary used and expressions that make sense to the target group. Son (2018) made several recommendations, which are currently considered essential for intercultural research, to compare translations of instruments without losing validity and reliability. Weiner's (2006) model is evaluated as being highly intuitive since it metaphorically compares different life situations to a typical jury trial, in which there is a fact to be judged by observers and the defendants themselves (self- and hetero-attribution). These judges go through an affective and cognitive process of cause attribution, which culminates in the interpretations and final judgment of the event and, consequently, in specific behavioral or attitudinal reactions.

It should be noted, however, that some terms proposed in Weiner's (2006) model are hard to adapt to Brazilian linguistic uses, such as the case of sympathy and schadenfreude. Sympathy and pity are used as synonyms and defined as the feeling of solidarity, when one notices that the cause of an event is uncontrollable. In Portuguese, this emotion has been translated as simpatia, since there is no consensus in social psychology about its definition, which has a closer meaning to the feeling expressed in the model. Schadenfreude is a word that only exists in German and means something similar to the pleasure derived from seeing someone else's suffering.

The word empatia (empathy) is not frequently used in Brazil because it is usually associated with simpatia (sympathy). Nevertheless, these words have different meanings: the Portuguese Language dictionary defines simpatia as a word derived from the Greek word sympátheia, accordance of feelings, through the Latin word sympathia, meaning the faculty of sharing someone else's joy or sadness (Ferreira, 1999, p. 1856). This definition alludes to the feeling of sharing, exchange and synergy between two or more people. In contrast, empatia is defined as a word derived from the Greek word empátheia, meaning the tendency to feel something that one would feel if one were in the 
situation or circumstances experienced by another person (Ferreira, 1999, p. 739). It is noted that this definition refers to the feeling of putting oneself in somebody else's place, as suggested by the American expression putyourself in someone's shoes. Empathy is associated with the attempt to see the world from another person's perspective. Naturally, when two people feel sympathy for each other, it becomes easier to engage in an empathic process.

The process of preparing instruments to interact with participants must be cautious, and it is necessary to use an appropriate language for the studied population, using expressions and words that are familiar to the research population (Kline, 2005). Since this research also aimed to investigate the role of emotions in Weiner's (2006) model and participants' understanding, it was decided to use the word empatia.

Moral emotions play a prominent role in the model, and they are classified into right or wrong, as well as the behavior, according to what is expected from each event. Weiner (2006) suggests that supporting this position is important, since not many specific studies are carried out into moral emotions in this type of articulation with behaviors investigated in social psychology.

There are, however, some studies that try to distinguish the types of emotions based on triggering situations. Sabini et al. (2001) used different scenarios for respondents to report how they would feel in those situations, and they found that the frequent theoretical association between shame and moral failings, as well as between embarrassment and violations of social conventions, was not empirically proven during the study. The results showed that the situations reflecting their own failure caused shame. On the other hand, situations reporting the possibility of other people thinking the failure was caused by the respondent himself or herself were associated with embarrassment. These situations led to anger when a situation in which other people thought that the respondent himself or herself was at fault for absurd reasons was described.

The discussion about Weiner's model applications in Brazilian studies has slowly progressed in the last few years, with empirical examination of the effectiveness of an intervention among Brazilian preservice student teachers (Ganda \& Boruchovitch, 2018), content analysis of TripAdvisor comments about hotels using Weiner's theory (Macedo et al., 2019) and compliance with a request of unethical nature in professional relationships in healthcare services (Rodrigues \& Assmar, 2003).

The literature on complaints and perceptions of justice is essential in research on services, as it problematizes strategies that consumers use to judge service failures and how they try to claim their rights in search of improvement and compensation. Likewise, these behaviors involve themes such as assertiveness, perception of persuasive tactics and norms. Thøgersen et al. (2009) verified that the probability of a consumer complaining depends on the perception about social norms and mainly on the perceived loss value regarding the product's defect. However, this type of conclusion is sufficiently vague and cannot be directly applied to a service context, especially a public and private education context, in which there are specific relations of status and power.

The conflict between consumers and employees occurs in different manners and between several actors. This is, therefore, an everyday phenomenon and a real problem for managers, who try to find ways to manage it in order to reduce the negative impact, both for the company's image before customers (external environment) and for employees themselves (internal environment). Given the inherent nature of conflicts in the work environment, it is advisable to make use of them when they occur to improve work processes and clarify divergences as a means of prevention. In organizations where there is a call center for customers, conflicts are particularly worrying, since they may involve employees and/or customers, associating consequences for the organization's internal environment with its external environment.

But what is the nature (punctual or routine) of the relationship between consumers and service clerks? Gutek (1999) classifies these interactions as service encounters and service relationships. Encounters are typical in bank branches, where each time a customer seeks service, this person finds different clerks, with a standardized treatment. Service relationships basically occur in more personalized services, such as housekeepers. They interact with the family to which they provide general services on a daily basis, and the interaction is different from that established by the bank teller. 
In case of on-site educational services, these are not service encounters, but "service relationships" instead, considering that there are reciprocal identification opportunities between the parties involved in the interaction (consumer and clerk), with a shared history of on-site or remote contacts, as well as expectations for future relationships. This coexistence must be guided by respect and acknowledgment of the importance of procedural justice, as the occurrence of conflicts entails the creation of a negative company image before consumers of this service.

In Weiner's (2006) attribution model, a set of attributions related to negative emotions is emphasized. Kalamas et al. (2008) analyzed the effect of anger caused by the attribution of service failures by users from different contexts (bank versus retail). They found that the more people felt angry at the situation described, the more negative their evaluation of the company's image and the worse their satisfaction with the service. Likewise, the more anger the participants reported, the more they were prone to complain and have less intention of purchasing or hiring the service again. These consumers also tend to give negative publicity of the product or service and seek the engagement of third parties, such as organizations that represent consumer rights.

In addition, with the aim of studying the main causes for complaint intention, Velázquez et al. (2010) argue that there are few studies on the effect of a product or service's familiarity on consumer behavioral intentions. They emphasize that even though complaint is understood as a cognitive response, it must be assessed as an emotional phenomenon as well. The content and form of complaint must be taken into consideration, along with their background: the importance consumers attach to that situation or product, and not only their dissatisfaction. The intention of complaining experiences effects of the consumers' attitude towards the complaining behavior, their level of information and their previous complaint experience. It is equally important to evaluate the perception of complaint success and the level of dissatisfaction of consumers, given the need to fulfill the expectations they create about a familiar service. In the first contact of a consumer, careful attention must be given, because their attitudes towards complaining increase their effect on the complaint intention.

In Brazil, there seems to be a general perception that consumers do not like complaining frequently, which can be interpreted as a consequence of mistakenly identifying social norms to complain. Chia and Sun (2020) discussed the term pluralistic ignorance to refer to the state in which there is a big contrast between self- and hetero-perception of norms. In the context of consumption, people may wrongly assume that other consumers' inertia means that they do not care about the failure that occurred and that they do not seem to take any initiative so that the failure is remedied, when they actually may be thinking the same of those who are observing them. Thus, the importance of providing consumers waiting for service with minimally satisfactory information, for example, is warranted. Simple and cheap solutions can minimize mistaken inferences about the cause of service failure, and they have a big impact on the evaluation and behavioral reaction of consumers.

Based on this argument, what are the reactions of VTE students to teacher tardiness and clerk service delay at the time of registration if they offer internal or external explanations? What are the differences in the evaluation of students between the types of simulated situations? These research questions, which do not seem to have been answered by the literature of the field, are the basis for the general and specific objectives of this work.

The objective of this study was to examine the relationship between emotions and cognitions of students in failure situations in the education service and their propensity to complain. From the perspective of the attributional theory proposed by Weiner (2006), a hypothesis was formulated in which, when detecting failure in the education service, a student goes through a cognitive and affective process. If the student interprets the situation as controllable and stable, with internal causes, typically he or she will hold the service clerks or teacher responsible (internal attribution). In this case, the tendency is to feel anger or other negative emotions and, consequently, express direct and indirect retaliation behaviors, such as oral and written complaints, boycott of classes, insubordination to authorities, among others.

On the other hand, if a student interprets the situation as uncontrollable and unstable, with external causes, he or she will not hold service clerks and teachers responsible (external attribution). The student tends to feel empathy or other positive emotions and, consequently, express behaviors of understanding, help or even praise the behavior of the person in that situation, as shown in Figure 1. 


\section{Figure 1}

Weiner's (2006) Causal Attribution Model Adapted to Negative and Positive Interpretations in Education Service Failures.

\begin{tabular}{|l|l|l|l|l|l|}
\hline $\begin{array}{l}\text { Types of service } \\
\text { failure }\end{array}$ & Types of causes & $\begin{array}{l}\text { Cause properties: locus, } \\
\text { stability, and } \\
\text { controllability }\end{array}$ & Responsibility & Emotions & Behavioral reaction \\
\hline
\end{tabular}

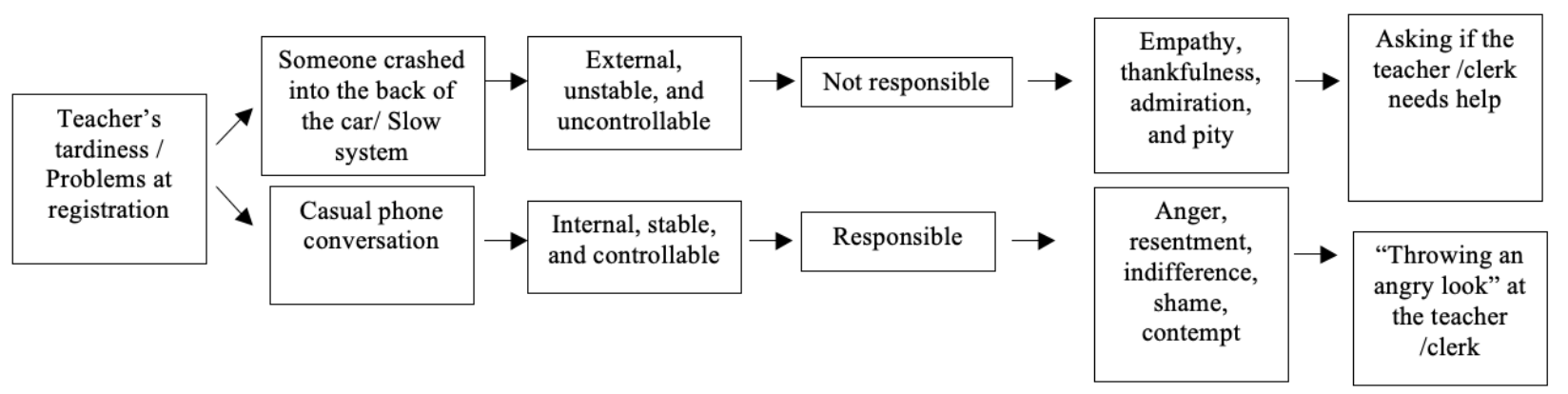

Thus, if the cause is considered to be stable, it means that some utilitarian objectives, such as a training program, will be perceived as unattainable, causing effects on punishment decisions and on means to deal with the situation. If it is considered to be unstable and temporary, more utilitarian objectives are emphasized, considering that there is the possibility that the situation will resolve over time. In this sense, if a causality is considered to be stable and controllable, the objective of punishment is particularly retributive, that is, the observer thinks the subjects "got what they deserved". Then, it is anticipated that there will be a difference between situations involving registration and teacher tardiness in terms of intensity of responses. Since the relationship with the teacher is usually more durable than the punctual encounter with the clerk, it is expected that students make more retributive evaluations. When evaluating the internal cause of a situation, participants are expected to attribute stronger negative emotions and negative reactions when they react to teacher tardiness than those responding to a situation of service delay.

It is also expected that, when making internal cause attributions, both while waiting for registration and while waiting for the late teacher, women report more negative emotions and reactions than men, according to the trend reported in studies comparing gender (Weiner, 2006). In order to operationalize the testing of these hypotheses, this research used scenarios that simulate these typical situations where a teacher arrives late to class and a registration is delayed in a service environment.

\section{METHOD \\ Participants}

Three hundred eighty-eight students (64.4\% male) aged between 14 and 57 years, of whom $71.4 \%$ had completed high school or were completing it, participated in the study. This is a nonrandom sample of three VTE schools of the same institution in the Brazilian Federal District. Subsamples were proportional to the number of students enrolled at each school, in such a way that the school with the lowest number of students participated with $19.3 \%$ of cases, the school with an intermediate contingent participated with $28.6 \%$ of cases, and the one with the highest number of students participated with $52.1 \%$ of total participants. Most students had never taken a course at the institution before (81.2\%), were doing a course in the administrative field (43.6\%), in the industrial learning modality (58\%). 


\section{Instruments}

The instrument was inspired by the empirical investigation of Weiner's (2006) theory conducted by Neves and Iglesias (2015), in which experimental scenarios were created with four versions in a between-subject design. In the latter study, high-school students evaluated their discomfort, acceptability, and probability of complaining, as well as their emotions towards the teacher's tardiness when he "overslept" or when his car tire got punctured. In both situations, the student imagined himself or herself arriving late or on time for the class, generating a 2 × 2 contingency matrix.

In this research, two situations of service failure were manipulated (teacher arriving late or delay in course registration), as well as these situations' cause (internal or external to the teacher and clerk, respectively). Four conditions were controlled in experimental scenarios from the theoretical model adopted, also resulting in a $2 \times 2$ between-subject design.

One scenario requested that the student imagined that he or she had arrived punctually for an important class, but the teacher arrived 30 minutes late, explaining that someone crashed into the back of his car while he was on his way to school (external cause, late teacher version, $n=96$ ). The second scenario simulated the student arriving punctually for an important class, while the teacher arrived 30 minutes late with no explanation, laughing while talking on the phone (internal cause, late teacher version, $n=95$ ). The third scenario, in turn, described the student waiting to register for a course that would start in 30 minutes. At the place where service is provided, the student notices that there are three people ahead also waiting for registration. However, the only clerk available explains that the system is slow and that he is carrying out registration as fast as he can while everyone waits (external cause, registration version, $n=98$ ). In the fourth scenario, the student is in the same waiting situation, but the clerk talks on the cell phone and laughs carelessly while the student waits (internal cause, registration version, $n=99$ ).

Following the description of the scenario versions, participants were invited to respond, on a scale of 0 to 10 , how much each of the eight sentences explained the situation described. The preparation of the items was based on Weiner's (2006) attributional theory, simulating internal causes towards the teacher or clerk (e.g., lack of effort and lack of motivation) and relational/interactional causes (e.g., stressful work environment and the clerk/teacher has power over customers/students). Participants then evaluated, from 0 to 10, how much they would feel nine emotions in those situations, including negative emotions such as anger and resentment, and positive emotions such as admiration and thankfulness. In order to evaluate the attributions of responsibility, controllability, and frequency, participants evaluated five items with an agreement scale from 0 to 10 (e.g., the teacher/clerk is responsible for the situation and the teacher/clerk is to blame for the situation).

Finally, participants expressed the probability from 0 to 10 of having different behavioral reactions. The version that mentioned a problem with the teacher's tardiness had 17 reactions (listed from the dialogues in the focus groups), while the version mentioning the problem with registration had 13 reactions. When comparing both situations, 12 reactions in common were identified among the situations, including: complaining to the unit's principal office and complaining to the clerk/teacher themselves. A socioeconomic questionnaire closed the instrument, with questions about gender, age, education, what course is being taken at the institution, and in which teaching modality. It also included an open question so that participants could freely write if they had any complaints to make to the educational institution.

\section{Procedures}

Initially, six focus groups were conducted at the three VTE units, with students from different modalities and periods (morning, afternoon, and evening periods) in order to collect recurring situations of education service failures that could constitute relevant content in an experimental scenario. Groups of 8 to 10 students from several courses in different study periods held discussions about the quality of the service they were using. The question script began with a question about how the study experience had been at the institution in which they are enrolled, how they evaluated the service based on feelings, what they thought about the education service, and ended with questions 
about the negative and positive aspects of the service and how it could be improved. During the discussions, students were urged to describe situations which they deemed as typical failures in the service they were using.

Based on the typical situations collected, a preliminary version of the questionnaire was prepared with 30 students, 10 from each institution, in order to check its semantic validity. After the due adjustments, the final version was created, and it was submitted to the principals of the three teaching units for approval of the classroom data collection. The collection was carried out in classrooms after the research proposal and the informed consent form were read. It was explained how long it took on average to respond to the questionnaire (around 15 minutes), and it was handed out afterwards. At that moment, the versions had already been randomly mixed so that students would not notice that there were different questionnaires.

\section{RESULTS}

The database underwent an exploratory analysis procedure first in order to check for the occurrence of missing values, typing errors, and extreme values. One participant was excluded because his response pattern was not consistent with the scenario condition and because he did not seem to understand the assignment. The assumptions that are relevant to each statistical test (normality and homogeneity of variances of each model variable) were analyzed, including the qualities of sample distributions, and no substantial threats to the analyses were identified that would require the exclusion of other data or transformation of variables.

Initially, a top-down reasoning was used, as there was already a solid theoretical model on which the questionnaire preparation was based. The components of the model were then represented by five sets of items: Internal causes, Relational Causes, Positive Emotions, Negative Emotions, and Negative R eactions. However, both the semantic grouping of items and the reliability indexes were not satisfactory and many items did not have a sufficient factor loading to constitute any dimension. Then, another factor solution was sought using a bottom-up reasoning so that the groupings emerged from participants' responses. Factor analyses with promax rotation indicated an adequate solution with 4 factors, accounting for $44.24 \%$ of variance, as described in Table 1: Negative Behavior (10 items, $\alpha=$ $0.83, \mathrm{KMO}=0.85$ ), Positive Reactions (9 items, $\alpha=0.77$ ), Internal Attributions ( 6 items, $\alpha=0.82$ ) and Negative Emotions (5 items, $\alpha=0.70$ ). The variable referred to as Negative Emotions concerns the reporting of emotions towards the scenario simulation.

Table 1

Structure and Factor Loadings of Students' Attributions, Emotions and Reactions.

\begin{tabular}{|c|c|c|c|c|}
\hline & \multicolumn{4}{|c|}{ Factors } \\
\hline & $\begin{array}{l}\text { Negative } \\
\text { behavior }\end{array}$ & $\begin{array}{l}\text { Positive } \\
\text { reactions }\end{array}$ & $\begin{array}{l}\text { Internal } \\
\text { attributions }\end{array}$ & $\begin{array}{l}\text { Negative } \\
\text { emotions }\end{array}$ \\
\hline Complain to the unit's board & .728 & & & \\
\hline $\begin{array}{l}\text { Write a complaint and place it in the } \\
\text { institution's suggestion box }\end{array}$ & .653 & & & \\
\hline $\begin{array}{l}\text { Complain about the event with family and } \\
\text { friends }\end{array}$ & .628 & & & \\
\hline Complain to the clerk/teacher & .621 & & & \\
\hline $\begin{array}{l}\text { Seek another academic institution to take the } \\
\text { course of interest }\end{array}$ & .525 & & & \\
\hline The institution is to blame for the situation & .504 & & & \\
\hline $\begin{array}{l}\text { Write a complaint about the event on social } \\
\text { networks (Facebook, Twitter, etc.) }\end{array}$ & .492 & & & \\
\hline $\begin{array}{l}\text { Vent about the event with other customers } \\
\text { waiting to be served/with colleagues }\end{array}$ & .445 & & & \\
\hline Anger & .377 & & .325 & \\
\hline $\begin{array}{l}\text { "Throw an angry look" at the clerk/teacher } \\
\text { The situation happens a lot } \\
\text { *Do not complain to anyone }\end{array}$ & .347 & & & \\
\hline
\end{tabular}


*Thankfulness $\quad .755$

*Admiration $\quad .749$

*The clerk/teacher is respected by students $\quad .671$

*Praise this behavior of the clerk/teacher to $\quad 602$

their superior (coordination or school board)
*The clerk/teacher has power over students

*Clerk/teacher's personality $\quad .520$

*Recommend the institution to acquaintances $\quad .396$

*Ask if the clerk/teacher needs help $\quad .348$

*Stressful work environment $\quad .315$

*Pity

Clerk/teacher's inadequate behavior $\quad .856$

Clerk/teacher's lack of effort $\quad .780$

Clerk/teacher's difficulty to organize .650

themselves

Clerk/teacher's lack of motivation $\quad .647$

$\begin{array}{lll}\text { The clerk/teacher is to blame for the situation } & .329 & .427\end{array}$

The clerk/teacher is responsible for the .410

situation

The situation can be controlled by the

clerk/teacher

$\begin{array}{lr}\text { Indifference } & .699\end{array}$

$\begin{array}{ll}\text { Contempt } & .661\end{array}$

$\begin{array}{ll}\text { Resentment } & .560\end{array}$

$\begin{array}{ll}\text { Shame } & .554\end{array}$

$\begin{array}{ll}\text { Empathy } & .409\end{array}$

Extraction method: Analysis of the Main Axes.

Rotation method: Promax with Kaiser

normalization.

a. Rotation converged in 5 iterations $\quad$ *Recoded items

In order to check whether the manipulation of the scenario versions has actually led to the intended interpretations of internal or external cause attributions, univariate analysis of variance (ANOVAs) were conducted for each factor according to the scenario version. There was a significant difference for all analyses $(p<0.001)$, suggesting a manipulation suitable to the study objective.

ANOVAs showed higher scores of negative behavior when the scenario simulated internal cause, either in case of registration delay or teacher tardiness, $F(3.383)=31.93, p<0.001, \omega=0.44$. Participants also showed higher rates of positive reactions when they responded to internal cause scenarios, $F(3.383)=10.05, p<0.001, \omega=0.26$. More internal attributions were made in internal cause scenarios, $F(3.381)=68.9, p<0.001, \omega=0.60$, as well as more negative emotions were reported in internal cause scenarios, $F(3.381)=22.08, p<0.001, \omega=0.38$. These differences are described in Figure 2.

Post hoc Tukey's tests showed that these differences were significant across all scenarios ( $p s<$ 0.001), except for some that compared versions of teacher tardiness and registration delay, rejecting the hypothesis of differences between those different service failure situations. Multivariate analyses of variance did not indicate differences in responses according to age range (adults and minors), participants' gender or teaching modality (industrial learning and other modalities).

Positive and significant correlations were found between internal attributions and negative behavior $(r=0.44, p<0.001)$, negative emotions and negative behavior $(r=0.45, p<0.001)$, and internal attributions and negative emotions $(r=0.42, p<0.001)$. However, it is observed that the more people reported positive reactions, the less they expressed negative behaviors $(r=0.16, p=0.001)$. 
Figure 2

Average Responses of Students According to the Type of Cause and Education Service Failure.

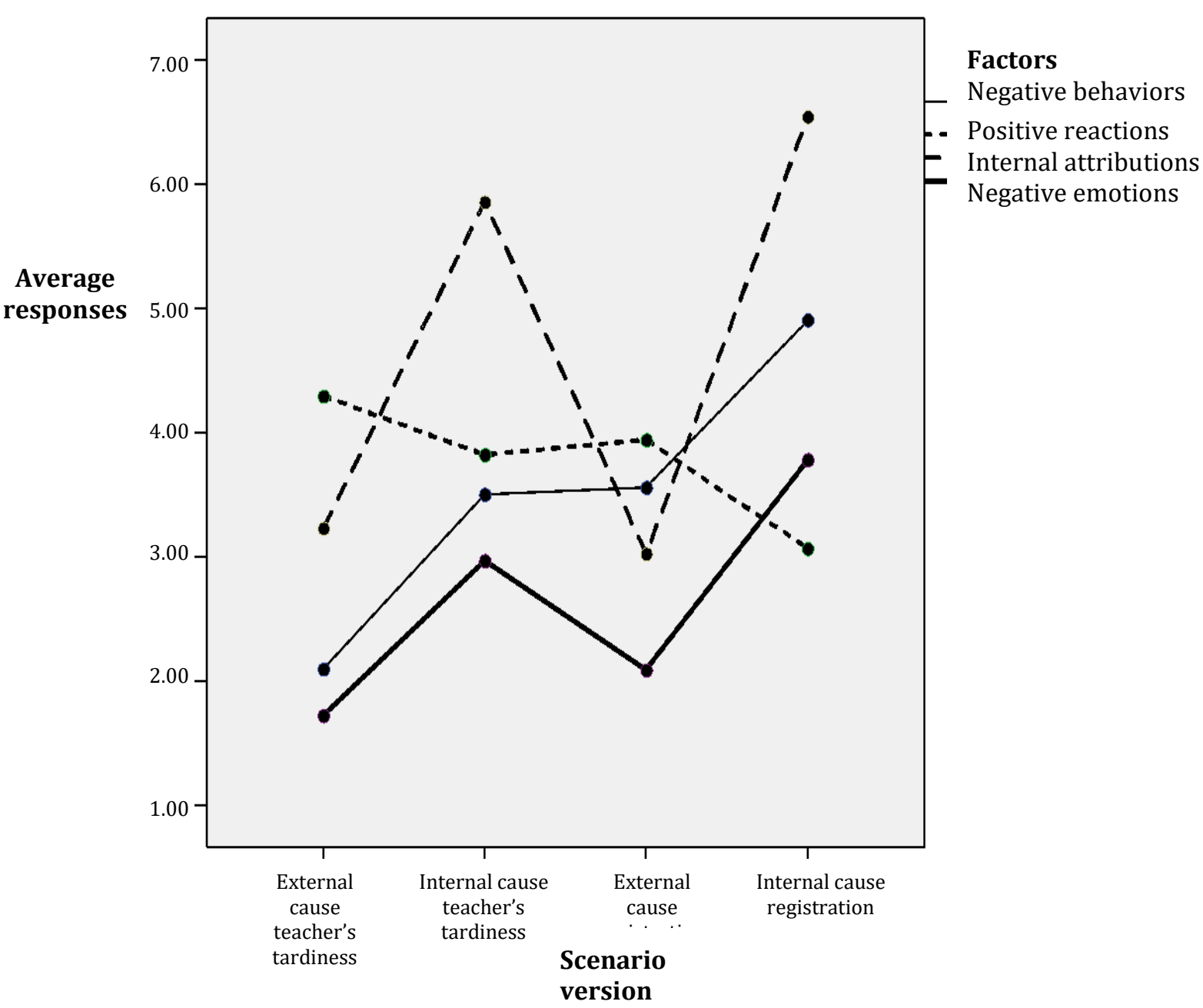

\section{CONCLUSION}

From the hypotheses formulated based on the theoretical model developed by Weiner (2006), using causal reasoning, analyses were performed in an attempt to answer the initial questions about how VTE consumers react when they notice a service failure. Despite the instrument's factorial configuration partially supporting the organization of variables predicted in the model, the predicted relationships were empirically confirmed. This decision of not forcing scale composition based only on theory is in accordance with Kline (2005), who recommends maintaining empirical configuration in many cases, even when there is a solid theory supporting the development of the items.

As hypothesized, the internal cause attribution process led to negative interpretations, emotions, and reactions, corroborating Weiner's (2006) theory. Despite respecting the theoretical prediction and inserting positive emotions and reactions in internal cause scenarios, this research was clearly oriented towards the complaint theme. These results add up to those of the few studies performed in Brazil with the same model, such as the ones that were tested by Neves and Iglesias (2015).

Items developed to refer to external attributions, positive emotions, and positive behavior separately were combined into a single factor: positive reactions. Theoretically, it would not be advisable to carry out any kind of analysis involving the positive reactions factor, but this variable was 
chosen to be included as a counterpoint to the attributional process involving internal causes, in search of practical explanations that are more loyal to the interpretation arising from participants.

Regarding the researcher's expectation of empirically replicating a theoretical postulate, Kline (2005) noticed the subtle and unintentional transmission of the researcher's expectations to the participant in laboratory experiments. The effects on participants' behavior can be dramatic, and those expectations also end up frustrating the researcher; on the other hand, the operational definition may be the most critical moment in the development of psychological measurements, as the applicability of a construct is tested. Since the instrument underwent a semantic validity test with a convenience sample, it is possible that the transposition of constructs was impaired at the moment the items were written. For example, the emotion empatia (empathy) was grouped into the set of negative emotions instead of positive emotions, as expected. The warning made by Son (2018) is of utmost importance in this case, as participants' responses seemed to have varied according to the interpretation of this word. It seemed to have been more associated with antipatia [antipathy] (as in the sense of "impathy"). During the semantic validation process with some groups, however, this negative interpretation of empatia emerged, but the researchers decided to maintain the dictionary meaning to submit it to the empirical test. Knowing the importance of emotions to explain complaints and other patterns of behavior shown by consumers (Kalamas et al., 2008; Sabini et al., 2001; Velázquez et al., 2010), this result can be used in future researches by varying the terms used in data collection instruments, as discussed by Kline (2005).

The emotion pena [pity], used by Weiner (2006) as a synonym for simpatia, had an ambiguous interpretation, which is why this item was excluded from the final factor solution. This emotion may have been interpreted as positive, as if the participant felt pity for the clerk who was alone and had to deal with a high-pressure situation and a slow system (more sympathetic meaning). There is also the possibility of a negative interpretation, as if the feeling of pity referred to the teacher who, feeling unmotivated by his job, was intentionally late to get in the classroom (feeling of superiority towards the object of pity).

These results guide a research agenda that investigates how different emotions of Weiner's (2006) model are interpreted in Brazil. Regardless of having a consensus about these constructs in social psychology, it becomes relevant to take Son's (2018) and Kline's (2005) warning into consideration in the preparation of research instruments, as well as asking directly what is the meaning of each emotion for a representative sample of the research, for semantic validation purposes.

Gender differences, predicted according to strong empirical tendencies (Weiner, 2006), were not significant. This may have occurred due to the clear diversity in the sampling profile, making comparisons between groups according to socio-demographic data difficult. This also occurred when differences of course modality and age ranges were tested, although they are variables considered to be important in the analysis of consumers' complaints. Education, evaluated as a sociodemographic information that differentiates consumers' behavior (Velázquez et al., 2010), did not vary, in such a way that it could not be associated with the other study variables.

The hypothesis of difference between scenarios according to the types of service failure could not be corroborated, as no significant differences were found for average responses as participants responded either to the registration environment or the classroom. Students possibly did not differentiate clerk from teacher, because they considered both of them as part of the same educational institution, building a negative image for all the service, regardless of having interacted with the teacher or the clerk.

Considering the interactions with the clerk or teacher, students might have imagined themselves in a service relationship (Gutek, 1999), as they are used to seeing the same people every day, from the doorkeeper to the course coordinator. High rates of negative behavior and reactions would be expected, as that was a service relationship, but the opposite was obtained. Possibly in a school, due to the power relationships involved, students feel uncomfortable to tell that they would complain directly to the teacher or clerk, even in a hypothetical situation. Besides, students were imagining only an occurrence of the situation in the scenario, and the stability of the service failure cause has not been clearly manipulated in the description of the scenario, unlike what Folkes et al. 
(1987) did. These works showed that, when adequately manipulated, the stability of a service failure also influences the decision to complain.

The emotions involved in the interactional process of a service are also related to the value attributed by the consumer to such service. If students believe that specific course can change the course of their lives, by offering better job opportunities, and realize that there is an important failure, they may have a higher probability of complaining, in light of the discussion made by Thøgersen et al. (2009). As a research agenda, the investigation of values associated with an education service is suggested, as this kind of service possibly defines a profile of consumers who are concerned about their ideological and professional education.

Finally, it is still necessary to reflect upon the practical implications of a study like this one. When a mistake is noticed during the provision of a service, both consumers and those who are responsible for the service (employees, managers, society as a whole) should report this failure. This report facilitates the identification and implementation of improvements in the service, enhancing its image and the tracking of gaps for the performance of employee training. The perception that Brazilian consumers are not used to complaining cannot be neglected. In this research, even though strong relationships between the negative attributional process and the intention to complain were detected, low negative behavior averages were found. This means that, among the attending students of VTE courses, a profile with low education level, there is little intention to complain. This information was found during the conduction of focus groups to prepare the instrument, which shows the importance of offering spaces and situations in which consumers, especially students, feel comfortable to complain about service. When failure is inevitable, the act of acknowledging it and providing students with an explanation shows respect and thoughtfulness regarding the potential embarrassment this failure may have caused.

Far from offering many opportunities for these consumers to complain about service, the service recovery guidance aims to use the opinions of main users, who deal more directly with its failures and advantages, in order to evaluate the service processes, computer systems, and environment of service provision, among other factors. This strategy enables service providers to effectively deal with dissatisfied consumers, considering variations of their behavioral style. By giving voice to, "hearing" and meeting the demands of a heterogeneous public such as VTE students, the educational service can show that it acknowledges the importance of these consumers' choices and that it is in fact oriented towards their satisfaction, effectively allowing the applications of social psychology to consumer behavior in favor of consumers themselves.

\section{Acknowledgment}

This research was supported by CAPES (a grant for the first author), CNPq (Universal Notice) and FINATEC (Foundation for Scientific and Technological Enterprises- Public notice for funding).

\section{Declaration of interest statement}

We declare that there is no conflict of interest.

\section{References}

Byun, J., \& Jang, S.(S.). (2018). Open kitchen vs closed kitchen: Does kitchen design affect customers' causal attributions of the blame for service failures? International Journal of Contemporary Hospitality Management, 30(5), 2214-2229. https://doi.org/10.1108/IJCHM-03-2016-0167

Chia, S. C., \& Sun, Y. (2020). Pluralistic ignorance. In J. Bulck (Ed.) The International Encyclopedia of Media Psychology. https://doi.org/10.1002/9781119011071.iemp0073

Ferreira, A. B. H. (1999). Novo Aurélio século XXI: O dicionário da língua portuguesa. [New Aurélio $21^{\text {st }}$ century dictionary: The dictionary of Portuguese language]. Nova Fronteira. 
Folkes, V. S., Koletsky, S., \& Graham, J. L. (1987). A field study of causal inferences and consumer reaction: The view from the airport. The Journal of Consumer Research, 13(4), 534-539. DOI: $10.1086 / 209086$

Ganda, D. R., \& Boruchovitch, E. (2018). Promoting self-regulated learning of Brazilian preservice student teachers: Results of an intervention program. Frontiers in Education, 3, article 5. DOI: 10.3389 /feduc.2018.00005

Graham, S. (2020). An attributional theory of motivation. Contemporary Educational Psychology, 61, article 101861. https://doi.org/10.1016/j.cedpsych.2020.101861

Gutek, B. A. (1999). The social psychology of service interactions. Journal of Social Issues, 55(3), 630617. https://doi.org/10.1111/0022-4537.00136

Harrison-Walker, L. J. (2019). The effect of consumer emotions on outcome behaviors following service failure. Journal of Services Marketing, 33(3), 285-302. https://doi.org/10.1108/JSM-042018-0124

Kalamas, M., Laroche, M., \& Makdessian, L. (2008). Reaching the boiling point: Consumers' negative affective reactions to firm-attributed service failures. Journal of Business Research, 61, 813-824. https://doi.org/10.1016/j.jbusres.2007.09.008

Kline, T. J. (2005). Psychological testing: A practical approach to design and evaluation. Sage. https://www.doi.org/10.4135/9781483385693

Macedo, C. P., Portela, G. F., \& Freitas, A. A. F. (2019). As interações virtuais entre clientes e gerência de hotéis do Brasil: Um estudo sob a ótica da Teoria da Atribuição [The virtual interactions between customers and hotel management in Brazil: A study from the viewpoint of Attribution Theory]. Caderno Virtual de Turismo, 19(3). https://doi.org/10.18472/cvt.19n3.2019.1552

Neves, L. M. G. S., \& Iglesias, F. (2015). Teacher's punctuality: Causal attributions by students in class. Arquivos Brasileiros de Psicologia (on-line), 67(3), 62-74. Recovered from http://pepsic.bvsalud.org/scielo.php?script=sci_arttext\&pid=S1809$52672015000300006 \& \operatorname{lng}=p t \& t \operatorname{lng}=\mathrm{pt}$

Qiu, S.(C.), Li, M., Mattila, A. S., \& Yang, W. (2018). Managing the face in service failure: The moderation effect of social presence. International Journal of Contemporary Hospitality Management, 30(3), 1314 - 1331. https://doi.org/10.1108/IJCHM-06-2016-0315

Rodrigues, A., \& Assmar, E. M. L. (2003). Influência social, atribuição de causalidade e julgamentos de responsabilidade e justiça [Social influence, causal attribution, and judgments of responsibility and justice]. Psicologia: Reflexão e Crítica, 16(1), 191-201. http://dx.doi.org/10.1590/S010279722003000100020

Sabini, J., Garvey, B., \& Hall, A. L. (2001). Shame and embarrassment revisited. Personality and Social Psychology Bulletin, 27, 104-117. https://doi.org/10.1177/0146167201271009

Son, J. (2018). Back translation as a documentation tool. The Translation \& Interpreting, 10(2), 89-100. https://search.informit.org/doi/10.3316/informit.864953916346703

Srivastava, M., \& Gosain, A. (2020). Impact of service failure attributions on dissatisfaction: Revisiting attribution theory. Journal of Management Research, 20(2), 99-112.

Thøgersen, J., Juhl, H. J., \& Poulsen, C. S. (2009). Complaining: A function of attitude, personality, and situation. Psychology \& Marketing, 26(8), 760-777. https://doi.org/10.1002/mar.20298

Velázquez, B. M., Blasco, M. F., Saura, I. G, \& Contrí, G. B. (2010). Causes for complaining behavior intentions: The moderator effect of previous customer experience of the restaurant. Journal of Services Marketing, 24(7), 532-545. https://doi.org/10.1108/08876041011081087

Weiner, B. (2006). Social motivation, justice, and the moral emotions: An attributional approach. Lawrence Erlbaum. https://doi.org/10.4324/9781410615749 